\title{
Constitutionalism and War Making
}

\author{
War Powers: The Politics of Constitutional Authority. By Mariah \\ Zeisberg. Princeton, New Jersey: Princeton University Press, 2013. \\ 288 pages. $\$ 29.95$.
}

Long Wars And the Constitution. By Stephen M. Griffin. Cambridge, Massachusetts: Harvard University Press, 2013. 376 pages. \$39.95.

\section{Reviewed by Peter M. Shane*}

When President Obama, in August 2012, explicitly requested statutory authority for a military strike against Syria, Americans witnessed a political event without modern precedent: a president explicitly inviting full-blown congressional deliberation regarding a discrete military strike calculated not to start all-out war. ${ }^{1}$ The gambit was derided by some as a signal of political weakness ${ }^{2}$ and applauded by others as a gesture of constitutional respect. $^{3}$ Either way, the debate tested the coherence of the President's war aims, vetted the intelligence on which his strategy was based, and probed the sufficiency of his planning for both the strike and its aftermath. The substance of the debate shaped not only the committee's draft authorization for the use of military force ${ }^{4}$ but, quite likely, the President's subsequent turn to multilateral diplomacy as an alternative strategy for deterring the Assad government's use of chemical weapons. ${ }^{5}$

Two thoughtful new books on war powers advocate just this kind of interbranch dialogue as a way of fulfilling the original constitutional design regarding the deployment of military force. Such debate exemplifies what Tulane law professor Stephen M. Griffin considers the constitutionally

* Peter M. Shane is the Jacob E. Davis and Jacob E. Davis II Chair in Law, Moritz College of Law, Ohio State University. I am grateful to Garrett Epps, Marty Lederman, Dakota Rudesill, Chris Walker, and participants in a September 19, 2013, faculty workshop at the University of Texas School of Law for thoughtful comments on an earlier version of this Review.

1. Carol E. Lee \& Janet Hook, Obama Presses Syria Gamble, WALL ST. J., Sept. 2, 2013, http://online.wsj.com/news/articles/SB10001424127887323932604579051190561274858?KEYW ORDS $=$ Obama + Syria+Congress.

2. Charles R. Kesler, No Thanks, Mr. President, NAT’L Rev. Online (Sept. 5, 2013, 4:00 AM), http://www.nationalreview.com/article/357658/no-thanks-mr-president-charles-rkesler.

3. Jack Goldsmith, Congratulations President Obama, LAWfARE (Aug. 31, 2013, 3:19 PM), http://www.lawfareblog.com/2013/08/congratulations-president-obama/.

4. See S.J. Res. 21, 113th Cong. (as reported by S. Comm. on Foreign Relations, Sept. 6, 2013).

5. Mark Landler \& Jonathan Weisman, Obama Delays Syria Strike to Focus on a Russian Plan, N.Y. TIMES, Sept. 10, 2013, http://www.nytimes.com/2013/09/11/world/middleeast/syrianchemical-arsenal.html?_r=0. 
intended "cycle of accountability." Likewise, had a military strike ensued, the deliberations, as much as any formal outcome, would have enhanced what University of Michigan political scientist Mariah Zeisberg calls the "constitutional authority" of such an initiative. ${ }^{7}$ Although plainly aware that the Constitution's allocation of war powers is intended as law, both authors argue that the robustness of deliberations such as these, rather than the legality of military intervention per se, ought to be the focus of the public's concern with regard to war making. Even as a constitutional matter, they contend, the quality of our elected officials' decision-making process should matter more to Americans than whether military action is "legal" or "illegal."

As I discuss below, both the Zeisberg and Griffin volumes creatively attack the problem of constructing constitutional meaning for a critical aspect of the government's founding document-its allocation of war authorities - that generally escapes judicial interpretation and enforcement. But each, as I will also elaborate, springs too quickly to dismiss law as a significant force for the very kind of institutional behavior they so urgently seek. Congress and the Executive are routinely involved in the production, review, and application of law, even when their interpretations are not likely to be reviewed in court. ${ }^{8}$ Actors within the political branches consequently do and should think of themselves as obligated to frame within a principled legal framework their deliberations over the exercise of government power, and this legal framing is critical to understanding the institutional dynamics and substantive outcomes that attend such deliberations. ${ }^{9}$ War making is no exception. The Syria episode is a powerful illustration of how the legal framing of war powers decision making can help catalyze productive political deliberation. Our challenge is how to institutionalize that law-driven interbranch dialogue.

6. See STEPHEN M. GRIFFIn, LONG WARS AND the CONSTITUTION 4-5 (2013) ("The cycle is a handy way of capturing what occurs when ordinary interbranch interaction is extended over time.").

7. See Mariah Zeisberg, War Powers: The Politics of Constitutional Authority 45-46 (2013) (suggesting that "constitutional authority" derives from "the processes of knowledge production and interbranch deliberation").

8. See id. at 6-7 (suggesting that some of the laws of Congress are not likely to be reviewed in court by noting that the United States Supreme Court's power to interpret the Constitution is implied, rather than explicit, and that "the judiciary has chosen to limit its scrutiny of 'political questions' like the nature of constitutionally authoritative procedures for going to war”).

9. This argument has been made by Professors David Barron and Martin Lederman with specific regard to war making. David J. Barron \& Martin S. Lederman, The Commander in Chief at the Lowest Ebb - A Constitutional History, 121 HARV. L. REV. 941, 1106-10 (2008); David J. Barron \& Martin S. Lederman, The Commander in Chief at the Lowest Ebb - Framing the Problem, Doctrine, and Original Understanding, 121 HARV. L. REV. 689, 721-25 (2008). 
I. Mariah Zeisberg and the "Relational Conception" of Constitutional Authority

Perhaps surprisingly, the question implicitly framing the political scientist's book is the more straightforwardly normative of the two. Mariah Zeisberg's War Powers: The Politics of Constitutional Authority seeks to recast in a more useful way the familiar question, When are presidential war making (and congressional initiatives regulating war making) consituational? Her aim is to identify, justify, and apply meaningful new "standards for assessing interpretive fidelity" to the Constitution by both Congress and the President. ${ }^{10}$ Recognizing the centrality of the elected branches rather than courts in constructing the meaning of constitutional war powers, she advocates standards that transcend the usual norms attached to judicial decision making in favor of norms "that capture, track, and engage ... constitutional politics." $" 1$

For many legal scholars, of course, politics is the conspicuous stumbling block in reconciling the elected branches' behavior with a view of the Constitution as war powers law. Because the elected branches disagree as to the proper interpretation of the relevant text, ${ }^{12}$ and there is no realistic prospect of the courts or any other authoritative third party settling their disagreement, ${ }^{13}$ it is politics, not law, that is arguably the only significant source of constraint on their behavior. This institutional reality, Professor Zeisberg suggests, is inimical to the operation of the Constitution as law, however, only if we accept two conventional, but dubious, premises: first, that the relevant text must have a determinate and authoritative meaning, and second, that the determinate meaning must yield a rule that relevant actors can only obey or disobey. ${ }^{14}$ Professor Zeisberg argues, however, that both these premises are wrong. The Constitution, she asserts, can operate as law even in political contexts, ${ }^{15}$ even in the face of intractable interbranch disagreement, ${ }^{16}$ and even if we understand the text as

10. ZEISBERG, supra note 7 , at 10 .

11. Id.

12. Id. at $5-8$.

13. See id. at 8 (stating that there is no "final arbitrator" to decide the dispute).

14. See id. at 8-10 (discussing how the Constitution would ideally provide a resolution for basic political disputes and contain a policy controversy within a set of uncontroversial decision procedures that actors can rely on to assess the validity of their behavior).

15. See id. at 222 (noting that many constitutional problems, such as "impeachment," "the debt crisis," "appointments," and "governance overseas" are handled by looking to interbranch political interactions).

16. Id. at 41. I have taken the same position. Peter M. Shane, Legal Disagreement and Negotiation in a Government of Laws: The Case of Executive Privilege Claims Against Congress, 71 MinN. L. REV. 461, 461 (1987) [hereinafter Shane, Legal Disagreement]. On the applicability of the argument to war powers, see Peter M. Shane, Learning McNamara's Lessons: How the War Powers Resolution Advances the Rule of Law, 47 CASE W. RES. L. REV. 1281, 1298-300 (1997) [hereinafter Shane, Lessons]. 
posing the possibility of acting not just legally or illegally but rather "more or less" constitutionally, as a matter of degree. ${ }^{17}$

The key move for Professor Zeisberg is to understand the Constitution not only as allocating war-related authorities to the elected branches but also as erecting a particular institutional structure within which decisions regarding war making will be made. ${ }^{18}$ That structure is purposive; the relevant institutions-Congress and the President-were given different political foundations and different organizational configurations with the expectation that they would bring to governance different kinds of resources and governing capacity. ${ }^{19}$ As Professor Zeisberg sees it, then:

The availability of . . . textual, ideological, and institutional resources [created by the Constitution] for ordinary politics makes it appropriate to assess constitutional fidelity not only in terms of respect for a legal framework, but also in terms of officials' relationships to a structured politics that is created and sustained through constitutional language and institutions. ${ }^{20}$

In other words, Congress and the President should be regarded as faithful to the Constitution not only if (and perhaps not even if) they respect the rules with which the text delimits their respective powers but also if they make robust use of the capacities for governance that the Constitution intends that they exercise. Because this assessment requires an evaluation of each elected branch's interactions with the other, Professor Zeisberg calls her theory a "relational conception" of constitutional power. ${ }^{21}$

Under the relational conception, a person judging the elected branches' behavior will have two sets of standards in mind. One is substantive and looks to the bases on which the Constitution authorizes American war making. ${ }^{22}$ The other set Professor Zeisberg calls "processualist," ${ }^{23}$ but I will call "institutional" because "institutional" is the more familiar word and it captures Professor Zeisberg's thinking as well as her neologism. The institutional standards are implicit, she argues, in the structures and processes that the Constitution put in motion-processes through which the

17. ZEISBERG, supra note 7 , at 51-52.

18. See id. at 8-9 (suggesting that constitutional fidelity concerning war making should be determined, in part, through the ways that elected officials interact with their political institutions).

19. See The Federalist No. 51, at 317-18 (James Madison) (Clinton Rossiter ed., 1961) (arguing that each branch of government should be as independent as possible and have a will of its own in order to ensure the separate and distinct exercise of different powers of government between the three branches).

20. ZEISBERG, supra note 7 , at 9.

21. Id. at 41 (emphasis omitted).

22. Id. at 19.

23. Id. 
elected branches construct the meaning of the constitutional text through their interactions over military affairs. ${ }^{24}$

The substantive standards Professor Zeisberg identifies are "capacious," 25 to put it mildly. She thinks it a necessary, albeit not sufficient, condition for presidentially initiated war that it be defensive in nature. ${ }^{26}$ This limitation is presumably rooted in part in the familiar history of the drafting of Article I, in which the Framers gave Congress the power to "declare war," not "make war," in order to avoid the implication that the President could not, on his own, act to repel an invasion. ${ }^{27}$ It is rooted additionally in the presidential oath to "preserve, protect and defend the Constitution."28 Professor Zeisberg appears also to credit the idea that presidents lack authority to initiate wars of a certain scale- "wars that are expensive, time consuming, and pose heavy risks of casualties"29-although she is careful to argue that the Constitution does not necessarily exempt smaller scale conflicts from a requirement of congressional authorization. ${ }^{30}$

Professor Zeisberg does not directly address the issue of substantive standards to govern Congress's initiation of war. Professor Zeisberg poses as a question whether Congress should be deemed authorized to initiate aggressive, as well as defensive war, ${ }^{31}$ although her treatment of the Mexican War suggests an affirmative answer. ${ }^{32}$ Implicitly, this means that the only substantive standard confining Congress is that authorizations of war must advance "the common Defence and general Welfare of the United States." 33

The real punch for Professor Zeisberg thus stems from her institutional, or "processualist," standards. The Constitution, she argues, makes certain categories and distinctions substantively relevant, e.g., "war," "repelling attack," and defense. ${ }^{34}$ Because the effective meaning of these categories and distinctions "must be politically constructed,"35 it is of utmost importance to the idea of constitutional fidelity that the political branches give effect to those categories in ways that the Constitution intends for those institutions to function.

24. Id. at 40

25. Id. at 247.

26. Id. at 20.

27. See Louis Fisher, Presidential WAR POWER 6-7 (1995).

28. U.S. CONST. art. II, § 1; ZEISBERG, supra note 7, at 20.

29. ZEISBERG, supra note 7, at 19-20.

30. Id. at 20 .

31. Id.

32. See id. at 83 (suggesting that the War's implications for slavery required more deliberation by the legislature than was given but not that Congress lacked authority, upon due deliberation, to initiate war against Mexico).

33. U.S. CONST. art. I, § 8.

34. ZEISBERG, supra note 7, at 21.

35. Id. 
Professor Zeisberg's core argument is that normative standards for judging the elected branches' performance in war-related decision making may be deduced from three structural features of the Constitution. The first is that each elected branch enjoys an independent source of political authority; though our two political branches comprise three elected institutions-House, Senate, and President-that are popularly elected, constituency preferences for each are transformed into actual institutional membership under significantly different conditions. ${ }^{36}$ Second, both Congress and the Executive Branch have distinctive governance capacities supported by their respective particular structures. ${ }^{37}$ Finally, the Constitution assigns to the branches shared powers. ${ }^{38}$ As a result, the two elected branches' exercise of power brings them into a relationship that may activate the possibilities for conflict inherent in their independent sources of authority and different perspectives on governance. ${ }^{39}$

In Professor Zeisberg's view, each of these constitutional features yields a normative standard for assessing the elected branches' constitutional fidelity with regard to war making. The branches' structural independence yields a norm of independent judgment, requiring each branch to "view itself as authorized and equipped to judge the constitutional and policy claims that it confronts while conducting its business." 40 The distinctive governance capacities of the branches resulting from their different structures generates a norm that each branch "exercise[] its powers... in ways that are connected to its relative governance strengths." 41 For the broadly representative Congress, those strengths include the capacity to "create[] and express[] divergent paths of reasoning, on both policy and constitutional matters." ${ }^{22}$ Congress also has unique capacity, Professor Zeisberg asserts, "to pool and weigh information from multiple sources, and to generate large understandings of public policy on the basis of complex information." 43 For its part, the hierarchically organized Executive can draw on its intelligence, diplomatic, and military

\section{Id. at 25.}

37. Id. at 26 .

38. Id. at 29-30.

39. Id.

40. Id. at 32 .

41. Id. at 37. At different points, Professor Zeisberg seems to characterize slightly differently what she takes to be the normative implications of the different branches' governance capacities. Initially, she infers from these capacities two norms: (1) that their reasoning over public policy be "sensitive to the security realities they encounter" and (2) that the branches "link their arguments about constitutional authority to their substantive agendas for security policy.” Id. at 32-33 (emphasis omitted). The formulation I have quoted above encompasses both of these ideas.

42. Id. at 37 (emphasis omitted).

43. Id. (emphasis omitted). 
establishments to inform its war-making policy in nuanced and evidencebased ways. $^{44}$

The third structural feature to which Professor Zeisberg refers, the centrality of shared powers, implies an obligation that each branch deploy its authorities in ways that facilitate response by the other. As Professor Zeisberg puts it:

Branches that accompany their uses of the shared war power with a policy and constitutional position that the other branch may judge, and that use their powers in ways that are more rather than less responsive to the positions of their rivals, generate more constitutional authority for their behavior and for the larger warmaking system. ${ }^{45}$

What the elected branches produce when they conform their behavior to these normative standards is not "legality," but "constitutional authority." 46 Professor Zeisberg is somewhat elliptical on what "constitutional authority" means-a topic to which I will return-but it permits two features that seeking "legality" would not. The first, as suggested above, is that it is not binary. ${ }^{47}$ If legality is our rubric, then war is either lawful or not. With constitutional authority as the lodestar, war making can have more of it or less of it; authority exists on a continuum. ${ }^{48}$ Second, authority can be earned with regard to war making even under conditions of interbranch conflict. Conflict, according to Professor Zeisberg, does not mean either branch is in violation of the Constitutionwell-structured conflict may nonetheless produce constitutional authority if both branches are deploying their capacities well. ${ }^{49}$

\section{Stephen M. Griffin on “Constitutional Orders” and Constitutional Change}

Like Professor Zeisberg, law professor Stephen M. Griffin is deeply concerned with the quality of institutional practice and interaction in connection with war making. Unlike Professor Zeisberg, however, he does not advocate the reframing of what counts as "law" to incorporate into the idea of constitutionality any particular standards of institutional effectiveness. For Professor Griffin, constitutional law comprises judicially generated and enforceable doctrine. ${ }^{50}$ What he critically discerns, however,

44. Id. at 35 .

45. Id. at 38 (emphasis omitted).

46. Id. at 46 .

47. See id.

48. Id. at $46-47$.

49. Id. at 41 .

50. GRIFFIN, supra note 6, at 11 (asking the reader to imagine a world where war powers are legalized (or judicialized)). 
is that "beginning with Korea an amendment-level constitutional change"51 occurred with regard to the constitutional rules of war making. Specifically, he argues, after World War II, presidents and many members of Congress came to believe that the Constitution empowers the President to initiate war without prior legislative authorization. ${ }^{52}$ Professor Griffin persuasively explains that this construction of Article II is at odds with the original understanding of the Constitution, namely, that Presidents may initiate war only with congressional authorization. ${ }^{53}$ This is a view he further asserts was the consensus interpretation of the Constitution with regard to military affairs until the advent of the Cold War. ${ }^{54}$

The question thus framing Professor Griffin's book is not, When is war constitutional?; but rather, How did the rules regarding the constitutionality of war change without formal constitutional amendment? His answer is that the process of constitutional construction-determining the rules that follow from the constitutional text-depends not just on the text but also on what he calls a "constitutional order." 55 A constitutional order, in Professor Griffin's theory, comprises both the text of the Constitution and the "multiple independent and distinctive institutions,... which mediate[] constitutional meaning."56 The latter specifically include the "political and policy objectives of government officials, elites and the public," and, very importantly, the "structure and capacity for action of state institutions." 57 A constitutional order arises when these elements combine in "relatively stable patterns of institutional interaction with respect to basic aspects of the Constitution such as powers and rights."58

At the time of our founding, the constitutional order surrounding war powers thus encompassed more than just the Article I text that so conspicuously assigns policy priority to Congress with regard to military matters. It also included, among both the general public and our early policy elite, a "pervasive fear of excessive executive power." 59 A warweary polity was determined to guard against unilateral Executive war making. Self-defense for the new nation had nothing to do with what we would today call "global security," and everything to do, quite literally, with immediate national self-preservation. It is evident from the

51. Id. at 48 .

52. Id. at 49.

53. Id. at 35-40 (discussing the ratifying debates and concluding that it is clear that Congress alone possesses this power).

54. Id. at 7.

55. Id. at 4.

56. Id. at 14 .

57. Id.

58. Id.

59. Id. at 44 (internal quotation marks omitted). 
Constitution's text that the national government was to have only limited capacity even for that purpose. ${ }^{60}$

Professor Griffin refers to "three dimensions of a constitutional order: [1] plausible interpretations of the text linked to [2] attractive visions of public policy that can be implemented through ... [3] the capacities of state institutions." ${ }^{61}$ Under the original constitutional order, unilateral, presidential, war-making authority would not have been an attractive vision; it smacked too much of monarchy. Nor did the Executive Branch have any stable or sizeable military establishment with which to implement such a vision. ${ }^{62}$ Both the text of the Constitution and common memory of the context in which it was written would have made it implausible to argue that presidents could take the United States to war without specific legislative license. ${ }^{63}$ Notwithstanding numerous examples of U.S. military deployment throughout the nineteenth and the first half of the twentieth century, the original position - that Congress has to authorize war-was repeatedly reaffirmed until the Cold War by numerous "important public officials, including presidents and justices of the Supreme Court."

What happened during the early years of the Cold War did not entail any change to the constitutional text. Textual change was unnecessary to generate constitutional change because the effective meaning of the Constitution is worked out in what Professor Griffin calls "the nonlegalized sphere" 65 of the Constitution-that is, in the interaction of our elected institutions with little judicial involvement. In this sphere, with little regard for constitutional wording, the evolution of new policy priorities coupled with the creation of innovative state capacities effectively generated new constitutional powers. ${ }^{66}$ Professor Griffin argues that it was the coincidence of new policy and new capabilities which gave presidents the operational capacity to initiate war after 1945, and it is only that confluence of factors

60. It is well known that the Framers did not anticipate a standing army, providing specifically that appropriations to "raise and support Armies" not be granted for terms longer than two years. U.S. CONST. art. I, § 8.

61. GRIFFIN, supra note 6, at 55.

62. Id. at 59 .

63. Alexander Hamilton, the most "presidentialist" of the Founders, famously wrote that the President's war powers "would amount to nothing more than the supreme command and direction of the military and naval forces, as first general and admiral of the Confederacy; while that of the British king extends to the declaring of war and to the raising and regulating of fleets and armies.” THE FEDERALIST No. 69 (Alexander Hamilton), supra note 19, at 416. The latter powers, he continued, "by the Constitution under consideration, would appertain to the legislature.” Id.

64. GRIFFIN, supra note 6, at 53-54.

65. Id. at 16.

66. Id. 
that made plausible a reading of the Constitution that, contrary to the Framers' understanding, authorizes such initiative. ${ }^{67}$

Professor Griffin details the evolution of new policy and new capacity with great care. The emergence of the Soviet threat after World War II generated widespread support for a permanent increase in the nation's military capacity to meet that threat. ${ }^{68}$ Military alliances became essential to a strategy of containment and global stabilization. ${ }^{69}$ The experience of World War II substantially discredited the world view of isolationists in Congress, and post-war mobilization left intact, and under presidential command, "the most capable armed forces in the world." 70 Also, and quite profoundly, the advent of nuclear weapons — and Russia's acquisition of nuclear arms-made imaginable a kind of war in which the case for presidential unilateralism would obviously be most compelling. ${ }^{71}$ Due to missile flight times, a decision on retaliating to an incoming nuclear attack would have to be made in minutes or seconds, as would a decision on whether to launch a first strike if intelligence suggested Moscow was about to pull the nuclear trigger and much of its arsenal could be destroyed on the ground.

Against this background, President Truman advocated a substantial military buildup to maintain U.S. global supremacy and the security of both the United States and its allies in the face of a "long war" against Communist expansionism. ${ }^{72}$ America's newly ambitious view of its global security role more or less commanded a new reading of the Constitution:

As the fundamental strategy of the U.S. with respect to foreign affairs and national security, containment dictated the constitutional stance of the presidency with respect to war.... If that strategy involved the capacity to respond quickly to multiple foreign threats with overwhelming force, that meant the president had to possess the power to initiate military action, even war, as he saw fit. ${ }^{73}$

In short, a strategy of containment against the Soviet Union would not have been credible, either domestically or to the Soviet Union, if unilateral presidential military deployment were not understood on both sides to be a dependable foreign policy prerogative.

At the level of conventional legal interpretation, what made plausible a new reading of the Constitution under which the President had unilateral war-making power was the conflation of war making with foreign affairs.

67. Id.

68. Id. at 59 .

69. Id.

70. Id. at 60 .

71. See id. at $59-60$.

72. Id. at 60 .

73. Id. at 63 (emphasis omitted). 
As Professor Griffin notes, "the consistent later use of [Curtiss-Wright ${ }^{74}$ ] by executive branch lawyers in fact exemplified the post-1945 belief that war powers could be subsumed under foreign affairs, ${ }^{75}$ a domain in which the President concededly has important unilateral powers. ${ }^{76}$ This conflation obliterated a categorical understanding central to the founding generation's understanding of governmental powers, namely, that, among such powers, war making is simply different.

In terms of institutional capacity, however, it was not merely military capacity that changed with the Cold War. The capacities of the Executive Branch for intelligence gathering and interagency decision making were also transformed. For the first time, the creation in 1947 of the Central Intelligence Agency (CIA) ${ }^{77}$ gave the Executive Branch "a civilian intelligence agency that would function in both peace and war."78 Congress also created the National Security Council as a new instrument for coordinating security policy among key civilian departments and leaders of the military establishment, with direct accountability to the President. ${ }^{79}$ In 1949, Congress gave the CIA authorization to conduct covert operations, thus legitimating Executive initiative with regard to a specific form of adversarial operation that blurs the line between military and civilian engagement. ${ }^{80}$

74. United States v. Curtiss-Wright Exp. Corp., 299 U.S. 304 (1936), upheld the constitutionality of a joint resolution delegating authority to the President to impose an embargo on arms sales to Bolivia and Paraguay, which were embroiled in the Chaco War. Id. at 312-13, 329. Although the discretion Congress conferred upon the President would today seem utterly uncontroversial as the nondelegation doctrine is now interpreted, the Court, speaking through Justice Sutherland, used the case to advance novel propositions of foreign affairs law. See David M. Levitan, The Foreign Relations Power: An Analysis of Mr. Justice Sutherland's Theory, 55 YALE L.J. 467, 472 (1946) (describing Justice Sutherland's position as "radical”). The Court asserted, first, that the federal government derives its foreign affairs powers not from any constitutional grant, but rather from the fact of national sovereignty and, second, that participation in the foreign affairs powers of the United States is essentially limited to the President. CurtissWright, 299 U.S. at 318-19. The Court upheld the delegation, stating: "[W]e are here dealing not alone with an authority vested in the President by an exertion of legislative power, but with such an authority plus the very delicate, plenary and exclusive power of the President as the sole organ of the federal government in the field of international relations.” Id. at 319-20. The Court's views of the foreign relations power's sources and of presidential exclusivity have both been subject to substantial criticism. See, e.g., Louis Fisher, Presidential Inherent Power: The "Sole Organ” Doctrine, 37 PRESIDENTIAL STUD. Q. 139, 149 (2007) (explaining that much of the scholarly treatment of Curtiss-Wright has been "highly critical"); Levitan, supra, at 493 (calling Justice Sutherland's theory "extreme" and "an unfortunate departure from the long accepted and cherished notions as to the nature of the American system").

75. GRIFFIN, supra note 6, at 64 .

76. See id. at 7 (commenting that almost all presidents since Truman have claimed a unilateral power to wage war, supported by an "eminently defensible policy rationale”).

77. National Security Act of 1947, Pub. L. No. 80-253, § 102, 61 Stat. 495, 497-99 (codified as amended at 50 U.S.C. §§ 403-403x (2006 \& Supp. V 2012)).

78. GRIFFIN, supra note 6, at 101.

79. National Security Act of 1947 § 101.

80. GRIFFIN, supra note 6, at 102. 
In each of these post-war developments, Professor Griffin discerns an important lesson often missed by critics of unprecedented Executive power, namely, that the Executive Branch did not unilaterally expand itself. The presidency may have become "imperial" in terms of its asserted prerogatives and the accompanying threat to civil liberties, ${ }^{81}$ but it was not just presidents striking out on their own who created the modern national security state. Their capacities were undergirded by legislation that reflected a set of policy objectives and ambitions for their realization that had widespread support in both Congress and the general electorate. ${ }^{82}$

New governmental capacities in tandem with both a widespread assessment of the Communist danger and an equally widespread conviction as to the proper national strategy in response to that danger laid the groundwork for President Truman's unilateral commitment of U.S. troops to a "real war" in Korea. "Truman's decision," Professor Griffin writes, "was a departure from the Constitution and the American constitutional tradition." ${ }^{83}$ Yet there was no legal process available to enforce the original legal understanding. Popular support for the war was overwhelming at first, and the President was determined "to lay down a marker and establish a 'precedent' for the exercise of presidential war powers in the new circumstances of the Cold War." ${ }^{\prime \prime}$

Professor Griffin identifies three key constitutional ideas that came to be central to the post-World War II constitutional order. The first, and probably the most widely shared, is the idea of presidential supremacy in foreign policy. On defense and national security strategy, "Congress is effectively a junior partner, subordinate to the president." ${ }^{85}$ The second is "the erasure of a clear distinction between wartime and peacetime." 86 Acceptance of the idea that the Cold War was an ongoing "real" war, despite formal ends to both World War II and the Korean War, implied the legitimacy of tactics, including covert war, that might have otherwise seemed "repugnant." ${ }^{87}$ The third element is the assertion of unilateral presidential authority to initiate war. ${ }^{88}$ No president since Truman has committed U.S. troops to combat on the scale of Korea without some form of specific congressional authorization. ${ }^{89}$ But, with the exception of

81. Id. at 264.

82. See id. at 65-69 (detailing how the congressional support for the Marshall Plan and other foreign policy objectives, driven by fear of the Cold War, created foreign policy power in the Executive).

83. Id. at 71.

84. Id. at 73 .

85. Id. at 96 .

86. Id.

87. Id.

88. Id.

89. Id. 
President Eisenhower - who disavowed the existence of unilateral authority to aid the French at Dienbienphu in $1954^{90}$ —no president after Truman has described congressional authority to deploy U.S. troops in foreign combat as a constitutional necessity. ${ }^{91}$ Post-Eisenhower presidents seeking congressional authority for various forms of military commitment have uniformly asserted that they did not legally need that approval in order to deploy our armed forces constitutionally. ${ }^{92}$

Professor Griffin's core concern regarding this change in the constitutional order is not that presidents may engage in unconstitutional wars. He is explicitly reluctant to view presidential initiatives as "legal" or "illegal" if undertaken in contexts largely unguided by judicial decision making. ${ }^{93}$ Rather, his critical anxiety is about "the policymaking process for war" ${ }^{\prime \prime}$ - namely, that the new constitutional order, unlike the order it sought to displace, totally obviates what he calls the "cycle of accountability" that the old order implied for the sharing of war-making responsibility:

The cycle occurs when conflict and cooperation between the branches with respect to an area of policy like war powers are repeated across time. Each branch knows it will be judged by the other and by the people. Each branch thus feels the weight of responsibility and decision.... Each cycle increases the chance that policy the next time around will be formulated against the backdrop of "lessons of history." 95

As Professor Griffin documents, this cycle of accountability "has not properly operated with respect to foreign affairs after 1945."

What Professor Griffin identifies as missing in the political branches' interactions is the practice of mutual testing and deliberation over war, "an ongoing institutional practice in which both branches are held accountable., ${ }^{, 7}$ Under old order assumptions, a president intent on military action would need to persuade Congress of its merits, an exercise that would invite reflective discussion and require the Executive Branch to sharpen its thinking on key questions. A "legislative process to encourage deliberation" would in turn promote "war planning" and a clearer

90. Id. at $96,105$.

91. Id. at 96 .

92. Id. at 33; see also, e.g., Press Release, White House, Statement by the President on Syria (Aug. 31, 2013), available at http://www.whitehouse.gov/the-press-office/2013/08/31/statementpresident-syria ("I believe I have the authority to carry out this military action without specific congressional authorization ....").

93. See GRIFFIn, supra note 6, at 301 n.159.

94. Id. at 4.

95. Id. at 18 .

96. Id. at 5 .

97. Id. 
"discussion of war aims in the executive branch."98 What we would have, at least were the system to work effectively, would be exactly what Professor Zeisberg describes as the two branches' bringing “their special institutional capacities to bear on the problem of interpreting the Constitution's substantive standards about war."99

Because the cycle of accountability is, as Professor Griffin sees it, the key institutional arrangement motivating the Constitution's allocation of war powers, the lesson of the Korean War for Congress was just as destructive as what the Executive Branch took from the experience. ${ }^{100}$ Specifically, Congress learned that its acquiescence in presidential claims of inherent military authority would now give the Legislative Branch a constitutional excuse for evading political responsibility for war. ${ }^{101}$ Should a military adventure prove popular, Congress's votes to fund the war would earn the public's political approval. Should opinion turn negative- as it did in Korea-a quiescent Congress could pretend it was merely a bystander. The absence of explicit legislative approval would enable members of Congress to distance themselves from war making as if the now unpopular initiative were wholly the President's.

The United States has no doubt witnessed time and time again the failures of war planning and military policy making that breaking the cycle of accountability portends. Professor Zeisberg's account of the Polk Administration's duplicity with regard to the Mexican War amply demonstrates that, even under "original order"102 assumptions, the Executive Branch was fully able to undermine the interbranch deliberative process. $^{103}$ In more recent decades, despite the enactment of explicit authority for military action in both Vietnam and Iraq, presidents managed to so orchestrate the legislative process as to short-circuit real accountability. ${ }^{104}$ Presidential (and perhaps even congressional) conviction as to the superfluity of legislative approval provided an ideological excuse for fecklessness. For this reason, it is easy to spot a direct link between the logic of unilateral presidentialism and the pathologies of Executive Branch decision making that proved so disastrous in both Southeast Asia and

\footnotetext{
98. Id. at 75 .

99. ZEISBERG, supra note 7, at 18-19.

100. GRIFFIN, supra note 6, at 74-77.

101. Id. at 74.

102. Professor Griffin refers to the "original order" as the constitutional order of war powers envisioned by the Framers. Id. at 53 .

103. See ZeISBERG, supra note 7, at 78-83 (discussing how Polk misrepresented his position to Congress with regard to the Mexican War).

104. See GRIFFIN, supra note 6, at 123, 230-31 (discussing, first, how the Tonkin Resolution passed Congress with great applause but that obtaining legal support was not the primary goal of the resolution (it was driven by political motivations); and second, how the Bush Administration "had everything to gain" by asking Congress for advice about the war aims in Afghanistan and Iraq, but failed to do so).
} 
Iraq. ${ }^{105}$ Even if legal, these wars were conducted with a dismal caliber of Executive Branch decision making that was too little challenged in the Legislative Branch. Pre-World War II constitutional understandings did not guarantee responsible deliberation either within or between the political branches, but the post-World War II constitutional order has largely excused Congress from testing Executive Branch arguments over war aims and plans with sufficient rigor to strengthen presidential decision making.

\section{Jettisoning Law Too Hastily?}

The analyses of both Professors Zeisberg and Griffin are buttressed by illuminating historical treatments of wartime decision making. The interior chapters of the Zeisberg book offer instructive comparisons of institutional performance, between (1) the run-up to the Mexican War and the run-up to World War II, (2) congressional deliberations surrounding the so-called Roosevelt Corollary to the Monroe Doctrine and congressional participation in constructing the Cold War security order, (3) Executive decision making regarding the Cuban missile crisis and presidential decision making on the bombing of Cambodia, and (4) the Senate's investigation of the connection between business conduct and U.S. entry into World War I and the IranContra investigation. ${ }^{106}$ These comparisons amply show the usefulness of Professor Zeisberg's normative criteria for assessing the elected branches' behavior with regard to the regulation and making of war.

For his part, Professor Griffin not only complicates the "imperial presidency" narrative by placing Congress firmly in the picture, but he also clearly shows how the post-World War II constitutional order played out with negative institutional consequences in both Vietnam and in the postVietnam period, as well as with regard to U.S. war policy after 9/11. ${ }^{107}$ His book, viewed in tandem with Professor Zeisberg's, enacts an intriguing role reversal. The political scientist, Professor Zeisberg, connects her historical discussion more explicitly to a normative scheme for assessing the elected branches' constitutional authority. The lawyer, Professor Griffin, points more directly to the necessity for institutional change to reinvigorate the cycle of accountability he links to the original constitutional order. What directly unites the two books, however, is the authors' shared conviction

105. See Peter M. Shane, Madison's Nightmare: How EXecutive Power Threatens AMERICAN DEMOCRACY 56-81 (2009) (using the disastrous effects of the Vietnam and Iraq Wars to illustrate how unilateral presidentialism promotes bad military and policy decision making).

106. See ZEISBERG, supra note 7, at 54-91 (comparing the run-up to the Mexican war and the run-up to WWI); id. at 92-145 (comparing the Roosevelt Corollary and Congress's participation in the Cold War security order); id. at 146-83 (comparing the Cuban missile crisis and the bombing of Cambodia); id. at 184-221 (comparing WWI and the Iran-Contra investigation).

107. See GRIFFIN, supra note 6, at 120-52 (discussing the post-WWII constitutional order and its negative implications); id. at 153-93 (discussing the post-Vietnam period and its negative implications); id. at 194-235 (discussing the same after 9/11). 
that we should be less concerned with whether a presidential war initiative is or is not legal than we are with the quality of institutional interaction regarding war making - a regime of interaction intended to be catalyzed by the Constitution's structural design and allocations of war-making power.

The authors' shared conviction, however, runs the risk of pushing law out of the institutional picture too hastily. Some basic issues of war making are never going to be judicialized; courts are unlikely ever to pronounce particular wars legal or illegal. ${ }^{108}$ Nor would we want or expect the elected branches, in deciding about war, to use legality as the sole or even predominant criterion for their decision making. The Iraq War, for example, was constitutional but in many respects disastrous. But having the branches pursue their interaction in a more conspicuously legal frame would not only be appropriate as a matter of principle, but it could also help advance what I take to be each author's animating project, namely, revitalizing the elected branches' deliberative interactions regarding war making.

Consider the theory side first. It is true enough, of course, that judicial intervention in decisions about how and whether to make war is all but nonexistent. It is misleading, however, to call the war powers domain of the Constitution "nonlegalized."109 War-related decision making is deeply legalized in four conspicuous ways. First, the Constitution, which assigns the elected branches different roles with regard to war making, ${ }^{110}$ is law. Professor Griffin himself puts the point precisely: "Even in the sphere of the nonlegalized Constitution, the document is still supreme law. It is an available text providing a normative frame of reference against which shifting political events can be evaluated."111 Second, as part of Executive Branch decision making on war, government lawyers labor seriously (for the most part) over the precise question of whether the President's intended military operation is legal under both domestic and international law. Having served even briefly as a Justice Department lawyer, I am confident that the twenty-three post-1950 Executive Branch legal opinions that Professor Griffin cites in his appendix ${ }^{112}$ are but a miniscule slice of government lawyers' war-related analytic work; the list of published opinions fails to expose the undoubted occasional, but invariably confidential, advice that results in military initiatives not going forward, or not going forward as planned. Third, Congress regulates war making.

108. The nearest counterexample so far is The Prize Cases, 67 U.S. (2 Black) 635 (1862), which held that President Lincoln's blockade of southern ports after the attack on Fort Sumter, and the subsequent capture of ships attempting to run the blockade, were lawful exercises of the President's constitutionally based unilateral war powers. Id. at 669-71.

109. GRIFFIN, supra note 6, at 73.

110. U.S. CONST. art. I, §§8, 10; id. art. II, § 2.

111. GRIFFIN, supra note 6, at 73.

112. Id. app. 
Wholly apart from the War Powers Resolution, ${ }^{113}$ Congress has enacted dozens of statutory authorities that are triggered only by declarations of war or presidential determinations that war exists. ${ }^{114}$ Covert operations, which Professor Griffin properly identifies as central to the operation of the modern constitutional order, are governed by statute. ${ }^{115}$ Finally, even if courts are unlikely ever to determine categorically a war's legality, the availability of courts to enforce both domestic and international rules regarding the conduct of war is potentially of great consequence-as Presidents Truman and George W. Bush both learned. ${ }^{116}$ In all these senses, the domain of governmental war making is shot through and through with law.

Likewise, Professor Zeisberg's attempt to create a scheme of constitutional authority that emphasizes all but exclusively the quality of the branches' political interaction does not—and likely cannot—completely

113. 50 U.S.C. §§ 1541-1548 (2006 \& Supp. V 2012).

114. See Jennifer K. Elsea \& Richard F. Grimmett, Cong. Research SERV., RL31133, DECLARATIONS OF WAR AND AUTHORIZATIONS FOR THE USE OF MILITARY FORCE: HISTORICAL BACKGROUND AND LEGAL IMPLICATIONS 27-34 (2011).

115. See GRIFFIN, supra note 6, at 121 ("[I]n the post-1945 constitutional order presidents had unquestioned authority with respect to the use of nuclear weapons and covert military action . ...”); see, e.g., 50 U.S.C. § 413b (2006 \& Supp. V 2012) (governing presidential approval and reporting for covert actions).

116. See Youngstown Sheet \& Tube Co. v. Sawyer, 343 U.S. 582, 587 (1952) (refusing to uphold President Truman's Executive Order on the grounds that it was a lawful exercise of the President's military power); Boumediene v. Bush, 553 U.S. 723, 732-33 (2008) (holding that prisoners in Guantanamo, detained under the authorization of President Bush, had a right to petition for a writ of habeas corpus); Hamdan v. Rumsfeld, 548 U.S. 557, 567 (2006) (referring again to Guantanamo and holding that "the military commission convened to try Hamdan lacks power to proceed because its structure and procedures violate" the Uniform Code of Military Justice and the Geneva Convention); Hamdi v. Rumsfeld, 542 U.S. 507, 509 (2004) (referring again to Guantanamo and holding that "due process demands that a citizen held in the United States as an enemy combatant be given a meaningful opportunity to contest the factual basis for that detention before a neutral decisionmaker”); Rasul v. Bush, 542 U.S. 466, 484 (2004) (holding that Guantanamo detainees have a right to petition for habeas corpus). [AU1] Professor Griffin writes: "Surprisingly, until the detainee cases that followed 9/11, Justice Jackson's remarkable concurrence was not thought by executive branch attorneys even to be relevant to presidential decisionmaking concerning war.” GRIFFIN, supra note 6, at 92. The statement is incorrect, even as to published legal advice. For example, the Assistant Attorney General, in an opinion about deploying armed forces in Haiti, said:

[T]his is not, for constitutional purposes, a situation in which the President has "take[n] measures incompatible with the expressed or implied will of Congress," [Youngstown Sheet \& Tube Co.,] 343 U.S. at 637 (Jackson, J., concurring). Rather, it is either a case in which the President has acted "pursuant to an ... implied authorization of Congress," so that "his authority is at its maximum," id. at 635, or at least a case in which he may "rely upon his own independent powers" in a matter where Congress has "enable[d], if not invite[d], measures on independent presidential responsibility.” Id. at 637.

Letter from Walter Dellinger, Assistant Attorney Gen., to Senators Robert Dole, Alan K. Simpson, Strom Thurmond \& William S. Cohen (Sept. 27, 1994), available at http://www.justice.gov/olc /haiti.htm. 
suffice as a mode of constitutional analysis. This is easiest to see if one tries to identify the operational or even rhetorical significance of criticizing government action as lacking constitutional authority, if one does not mean to challenge legality.

For example, Professor Zeisberg recounts that, when she discusses her book project, "some mention the US entry into the Iraq War as a moment of constitutional deficiency"117 —an intuition bolstered, no doubt, by the Executive Branch's flailing in describing its war aims, by the failures of our intelligence agencies, by the Administration's inadequate war planning, and by Congress's hasty and ill-informed deliberations. ${ }^{118}$ It is not clear, however, what is added to the well-deserved indictment of the elected branches' abysmal institutional performance by describing it as a moment of "impaired constitutional authority" "119 or "constitutional deficiency," 120 as opposed to just "abysmal institutional performance." To the extent congressional authorization is a legal prerequisite to war making, no scholar has seriously argued that the 2003 invasion was unlawful as a domestic matter. ${ }^{121}$ Nor, to the extent that either Congress or the Executive Branch feels sufficiently chastened by the Iraq experience to do its job better the next time around does the constitutional-deficiency label seem to add to its already stark institutional incentives. Following Professor Zeisberg, one could accuse a President of war making that lacks constitutional authority without implying any transgression of legal limits; one could charge Congress with lacking constitutional authority in its deliberations, even if Congress has not failed to meet any legal obligation. But using a rhetoric of "constitutional authority" that is divorced from law in these ways feels a bit like saying that something is not just "bad," but "very bad."122

117. ZEISBERG, supra note 7 , at 47.

118. SHANE, supra note 105, at 68-76. Excellent full-length treatments of this subject include THOMAS E. RiCKs, FIAsCo: THE AMERICAN MilitARY ADVENTURE IN IRAQ (2006), and MiCHAEL R. GORDON \& BERNARD E. TRAINOR, COBRA II: THE INSIDE STORY OF THE INVASION AND OCCUPATION OF IRAQ (2006).

119. ZEISBERG, supra note 7, at 32 .

120. Id. at 47.

121. Whether the U.S. invasion of Iraq violated international law remains a subject of dispute. Compare John Yoo, International Law and the War in Iraq, 97 AM. J. INT'L L. 563 (2003) (defending legality of invasion), with Donald K. Anton, International Law and the 2003 Invasion of Iraq Revisited 12-13 (Apr. 30, 2013) (unpublished manuscript), available at http://ssrn.com/ abstract=2258842 ("In addition to the Arab League, the Non-Aligned Movement of 116 and several other states wrote to the Security Council to put on record their view that the use of force in Iraq by the 'coalition of the willing' was in violation of the UN Charter.").

122. To be fair, Professor Zeisberg does not position herself as a complete legality rejectionist; she states that her method "is not an antilegal method so much as one that transcends and embraces the 'legal."” ZEISBERG, supra note 7, at 223. For a war powers theory to "embrace the 'legal,"' however, that theory has to give law a more explicit role than appears in Zeisberg's account. 
Given these authors' common desire-a yearning I share-to see the elected branches make their war-making decisions more responsibly, the compelling task for constitutional theorists is this: Identify the stance towards law that government actors should have in order to maximize the likelihood of activating what Professor Griffin calls the cycle of accountability. Rather than remove legality from our frame of reference in thinking about war powers, we should ask how law might best be deployed to support optimal institutional interaction.

In this regard, I would argue that instead of urging decision makers to regard themselves as part of a "nonlegalized" constitutional domain, we should want government actors habitually to understand their official behaviors with regard to war making as acts of legal obligation or legally delimited discretion. ${ }^{123}$ In deciding what it is appropriate to do in their official capacities, they should weigh legal reference points in determining right and wrong, suitable and unsuitable. These reference points include the Constitution, statutes, judicial decisions, and legal opinions previously issued by attorneys general and the Office of Legal Counsel, as well as customary methods of legal interpretation by which officials routinely describe, justify, and thus normatively understand their governmental acts. They should do so even when no formal sanction exists to punish inattention to the relevant reference points. They should regard legal justification as an important factor even when other policy-driven or egocentric justifications would prompt the same behavior. I would argue, in short, that putting the law back into "law and politics" is a sensible move towards improving the branches' political performance.

To raise law's profile in the war powers domain may seem paradoxical given the emphatic reluctance of judges to say when wars are lawful. But, precisely because courts are unlikely to resolve key constitutional disagreements between Congress and the Executive, lawyers for both branches are positioned to take on a particularly responsible role. They can and should refrain from arguing as if they are merely advocates preparing briefs for a hypothetical third-party referee. Lawyers for both Congress and the President should hold themselves accountable to play independent, quasi-adjudicative roles in the elaboration of war-making law on behalf of their respective branches. Despite their likely disagreements, it is that common stance that is most likely to temper the antagonism of the elected branches with the public interest in workable governance. That is because no plausible congressional or Executive Branch war powers legal doctrine can completely ignore the capacities, interests, and prerogatives of the other

123. The stance towards law urged here with respect to interbranch war powers negotiation closely tracks my recommendations regarding interbranch executive privilege negotiations, in Shane, Legal Disagreement, supra note 16, at 484-501. 
branch. ${ }^{124}$ A quasi-adjudicative attitude is thus more conducive to working out over time a conscientious balancing of conflicting, legally relevant interests. Official understanding, explanation, and justification of government conduct is likely to be most responsible, and thus most consistent with workable governance, if the officials involved - and their lawyers-regard themselves as making, not just following, constitutional law.

Because the branches are likely to disagree on key principles, ${ }^{125}$ even if each interprets the Constitution in professionally responsible ways, doctrinal analysis is only half the picture. Government lawyers and their clients need to couple a commitment to conscientious legal analysis with a second institutional commitment-an ethos of negotiation that steers officials, while actually bargaining, away from the vindication of doctrinal principle for its own sake and toward the reconciliation of the competing institutional interests that each branch recognizes. ${ }^{126}$ Congress, that is, may always insist, in principle, that legislative authorization is prerequisite to lawful war making. ${ }^{127}$ Presidents may continue to insist on unilateral power in theory. ${ }^{128}$ The branches can "agree to disagree" in principle, however, so long as Congress is willing in practice to concede that some of its authorization may be implicit or indirect, and the President, in practice, effectively concedes that his initiatives are subject to congressional regulation.

The regime I have in mind of principled lawyering and pragmatic negotiation is perfectly consistent with Professor Zeisberg's criteria for the elected branches' constitutional authority. Rather than demand that the branches reach a settled legal consensus, I would urge each to come to a responsible, independent interpretation as to the allocation of war-making authority under the Constitution. Such lawyering would accord with the

124. See United States v. AT\&T Co., 567 F.2d 121, 127 (D.C. Cir. 1977) (stating that the Framers intentionally abstained from defining governmental powers in minute detail with the expectation that the branches would compromise with each other and seek "optimal accommodation" when a conflict in scope of constitutional authority arose).

125. See, e.g., Kucinich v. Obama, 821 F. Supp. 2d 110, 112 (D.D.C. 2011) (examining a conflict between the President's use of military action in Libya as an exercise of his "authority to conduct U.S. foreign relations" and select Congress members' views that this action violated the War Powers Clause).

126. Shane, Legal Disagreement, supra note 16, at 501; see also Peter M. Shane, Negotiating for Knowledge: Administrative Responses to Congressional Demands for Information, 44 ADMIN. L. REV. 197, 226-34 (1992) [hereinafter Shane, Negotiating for Knowledge] (suggesting one framework for reforming tensions between the Legislative and Executive Branches in the information-sharing context).

127. See U.S. CONST. art. 1, § 8, cl. 11 (giving Congress the authority to declare war).

128. John C. Yoo, Kosovo, War Powers, and the Multilateral Future, 148 U. PA. L. REV. 1673, 1688-95 (2000) (outlining the theoretical argument for and benefits of unilateral presidential war-making power). 
Zeisberg norm of independent judgment. ${ }^{129}$ To the extent the branches disagree on first principles, I would want each to negotiate in a manner respectful of what the other branch takes to be its core governance interests. This accords with Professor Zeisberg's prescription that the branches "use their powers in ways that are more rather than less responsive to the positions of their rivals." ${ }^{30}$ Finally, in negotiating over how or whether to proceed with any war-making project, I would ask that the negotiation take on the character of problem solving, rather than doctrinal vindication, which would mean that each branch would bring to the table its strongest evidence-based arguments for proceeding in one way rather than another. This would fulfill Professor Zeisberg's norm of connecting each branch's exercise of power to its particular governance strengths. A mutual commitment to the kind of legally framed, problem-solving negotiation regime I am advocating would do much to help restore the cycle of accountability central to Professor Griffin's analysis. Framing interbranch negotiation as enacting a governing regime of law could function not as a distraction from politics, but as a rubric to motivate more responsible politics.

There is, it should be said, one critical way in which the legal stance I am advocating departs markedly from the constitutional approaches of both Professors Zeisberg and Griffin. Although both writers seek a form of institutional interaction in which the relevant actors learn lessons from history, each resists the idea that a recognizable war powers law might be elaborated over time between the elected branches if they begin to treat historical experience as a source of something like legal precedent. ${ }^{131}$

129. ZEISBERG, supra note 7, at 31 .

130. Id. at 38 (emphasis omitted).

131. Both Professors Zeisberg and Griffin write critically of practice-based reasoning about constitutional rules, but their arguments should not be carried too far. Professor Zeisberg writes: "No plausible general theory of constitutional authority tells us that long-standing practice on its own is authoritative." Id. at 18. Arguments based on practice, however, are typically offered within a framework argument based on constitutional text and purposes. Practice "on its own" is rarely the issue.

In a similar vein, Professor Griffin observes: "Especially on the presidentialist side, participants [in these debates] tend to avoid the uncomfortable truth that the rule providing Congress the responsibility for authorizing war is supreme law and hence legally obligatory. Subsequent practice could not count against or nullify the rule without placing the entire Constitution in question." GRIFFIN, supra note 6, at 48 (footnote omitted).

Again, this analysis is persuasive to the extent practice is offered as the exclusive basis for reading the Constitution to vest the President with unilateral power to initiate full-scale "war"-a power recent presidents have claimed rhetorically, but none other than Truman has acted upon. What is often debated, however, is what counts as "war" under Article I and the level of explicitness with which Congress is obliged to authorize military engagement. Subsequent practice might well be thought helpful in constructing rules with regard to such questions, an interpretive proposition that is different from changing "rules in the Constitution," id., and which does not at all place the Constitution in question. 
Professor Zeisberg is emphatic on this point. She states that one way her "relational conception can be understood as 'political' relates to the limited place it gives to precedential reasoning." "32 She acknowledges that reference to precedent may assist officials in making good judgments and help assure the public that they are behaving reasonably. ${ }^{133}$ But Professor Zeisberg argues that the priority her theory gives "to the intersection between the constitutional capacities of the branches and the security context of the moment calls for decidedly presentist forms of justification. The relational conception prioritizes good judgment in the particular context over and above consistency across cases." ${ }^{\text {"34 }}$ To my mind, however, this call for "prioritization" seems like a bit of a red herring. A norm of consistency across historical cases will be predictably weaker in any decision-making context where politics plays a huge role. That is no reason to deny that the systematic reevaluation of historical examples can, over time, yield mutual interbranch understandings that take on the form of norms. International law is built substantially on the normative force of practice; there is no reason in principle why separation of powers law cannot follow suit. ${ }^{135}$

Professor Griffin's discontent with practice-based arguments may be more contingent. The practice-based arguments offered for unilateral presidential war-making power have, as he argues, been made sloppily and typically without any criteria for which interventions count and which do not. ${ }^{136}$ As a result, he asserts, the practice-based argument for unilateral presidential war making "has long been one of the most disreputable arguments ever made within separation of powers jurisprudence."137 Indeed, some of the precedents for presidential unilateralism on which modern presidents rely now seem linked to an imperialist program of the late nineteenth and early twentieth centuries that no president would now want to be associated with. As Professor Griffin writes: "It would appear difficult to base a contemporary argument for presidential intervention on obsolete foreign policies that later presidents officially repudiated.”"138 The argument Professor Griffin makes, however, is precisely the kind of lawyerly dispute over precedent that the legalized negotiation regime I

132. ZEISBERG, supra note 7 , at 250.

133. Id. at 251 .

134. Id.

135. See Christopher A. Ford, War Powers as We Live Them: Congressional-Executive Bargaining Under the Shadow of the War Powers Resolution, 11 J.L. \& POL. 609, 613-20 (1995) (arguing that the political branches' post-War Powers Resolution behavior had created an "effective law" of war powers); see also Shane, Lessons, supra note 16, at 1298-304 (suggesting that "custom [can be] a source of law in separation of powers disputes" and treating the behavior of institutional actors under the War Powers Resolution as an example).

136. GRIFFIN, supra note 6 , at 78 .

137. Id.

138. Id. at 84 . 
advocate would welcome. It should, indeed, be odious to cite U.S. procolonial interventions in China ${ }^{139}$ or repeated incursions into Central and South America ${ }^{140}$ as legal support for presidential war making, just as it would be to write a 2013 equal protection argument based on Korematsu $v$. United States ${ }^{141}$ or Plessy v. Ferguson. ${ }^{142}$ But that sounds like a productive and law-inflected argument for the political branches to have.

Professor Griffin unfortunately limits the deserved institutional reach of his own analysis by marginalizing debates over the legality of military deployments short of large-scale war. As noted above, he thinks judgments of legality are not useful in the absence of judicial precedent. ${ }^{143}$ He further

maintain[s] that the [war powers] debate should be centrally concerned with the ability of the executive branch to initiate war, "real" wars, major wars, rather than under what circumstances it can use military force to rescue citizens, intimidate the nation's enemies, and cooperate with allies and international organizations in humanitarian endeavors. ${ }^{144}$

Professor Griffin is correct, of course, that major wars exact extraordinary sacrifices and threaten the greatest harm to constitutional values. $^{145}$ But the fact remains that, apart from Korea-and notwithstanding various presidents' announced convictions-no real war has proceeded since Korea without some form of express congressional authority. ${ }^{146}$ The greatest harm wrought by presidential claims of unilateral authority to make real war is likely to be the spillover effect on lesser military engagements. It is hard to see how a cycle of accountability can be resurrected for military deployments, large or small, without resort to some theory of constitutional limits and obligations. Limits-and-obligations talk is the stuff of law.

\section{Can a Legally Informed Interbranch Negotiation Practice Be} Institutionalized?

Professors Zeisberg and Griffin are persuasive that U.S. constitutionalism would be better served by a more reliably accountable and

139. See, e.g., Jerome Alan Cohen, China and Intervention: Theory and Practice, 121 U. PA. L. REV. 471, 476 (1973) (discussing the nineteenth-century opening of China by western military force).

140. See supra note 73 .

141. 323 U.S. 214, 217-18 (1944) (effectively upholding the internment of JapaneseAmericans during World War II).

142. 163 U.S. 537, 550-51 (1896) (validating "separate, but equal” as the relevant standard in judging racially segregated public transportation facilities).

143. See supra text accompanying note 92.

144. GRIFFIN, supra note 6, at 30 (emphasis omitted).

145. See id. at 6.

146. See supra text accompanying note 89. 
deliberative interbranch relationship regarding war making. Whether described as a system of deeper constitutional authority, a new constitutional order, or the institutionalization of legally framed interbranch negotiations, an obvious question looms: Could any such system be brought about?

Professor Griffin's answer is not hopeful. He writes:

What Congress should be asking for today is for the executive branch to consistently engage with it on matters of foreign policy and national security strategy .... [D]oing this in a meaningful way will require Congress to change its structure, much as the executive branch was reorganized after $1945 .{ }^{147}$

The problem, that is, with our overreaching presidency does not lie exclusively with the ambitions of the Executive Branch. A profound obstacle to restarting a reliable cycle of accountability is that Congress is not so structured as to be an effective, coequal partner in foreign policy and national security deliberations. Although Professor Griffin does not deal with structural reform proposals in detail, the thrust of his thinking is clear: Congress needs to centralize authority in its leadership to deal with the Executive Branch in military affairs so that the President has credible, experienced consultation partners, who would be able-as the occasion calls for it - to mobilize their colleagues to support the President's national security plans going forward. Congress would also have to have processes in place adequate "to test the executive branch's claims with respect to war and foreign affairs in a way that works to the advantage of both branches and the nation as a whole." 148

Intriguingly, a promising first draft of a blueprint for reform could be a redraft of the War Powers Resolution introduced in 1995 by then-Senator Joseph Biden. ${ }^{149}$ Among other things, his so-called "Use of Force Act"150 would have set forth in far greater detail (albeit with more deference to the Executive than exists in the War Powers Resolution) Congress's

147. GRIFFIN, supra note 6, at 251.

148. Id. at 257. In the 1980s, the American Bar Association endorsed a set of measures for the more constructive resolution of interbranch disputes over access to Executive Branch information, notwithstanding profound differences between Congress and the President regarding the contours of executive privilege and its availability against Congress. Shane, Negotiating for Knowledge, supra note 126, at 231. Its suggestions, and a similar recommendation from the Administrative Conference of the United States, Recommendations of the Administrative Conference Regarding Administrative Practice and Procedure, 55 Fed. Reg. 53,269 (Dec. 28, 1990) (to be codified at 1 C.F.R. pts. $305 \&$ 310), were based on this author's study advocating the kind of legally framed interbranch negotiation regime for information disputes, Shane, Legal Disagreement, supra note 16, at 465-66, that I have also advocated for war making. The ABA specifically asked Congress to study the possible wisdom of creating a central body in Congress with continuing responsibility for executive privilege negotiations. Shane, Negotiating for Knowledge, supra note 126, at 234.

149. See S. 564, 104th Cong. (1995).

150. Id. § 1 . 
understanding of the permissible reach of presidential military authority. ${ }^{151}$ It would have also given the President the benefit of a statutory "Congressional Leadership Group" to facilitate interbranch consultation. ${ }^{152}$ A cycle of accountability could be yet further strengthened by creating in Congress "a single, principal point of oversight and review"153 for decisions about war. This could be either a joint committee or a single committee with jurisdiction in each house.

Unfortunately, nothing in Congress's track record sustains optimism for structural reform. Individual members may prize reelection even more than policy impact, ${ }^{154}$ but it seems a safe bet that most would prefer some personal committee roles that would assure a measure of visibility and the appearance of influence for each and every member. That reality and the ever-more-decentralized nature of political fund-raising ${ }^{155}$ have exerted a persistent centrifugal force on Congress that works to resist centralization initiatives. The kinds of reform needed for war deliberations resemble the kinds of reform that have been repeatedly urged for the system of congressional intelligence oversight. Seven of twelve intelligence and terrorism studies between 1991 and 2001 recommended congressional restructuring; Congress did nothing. ${ }^{156}$ The 9/11 Commission recommended that Congress create "a single, principal point of oversight and review for homeland security." 157 It has not happened. ${ }^{158}$

As I have argued elsewhere, however:

Remarkably,... it is possible in the current political moment to imagine a confluence of political forces that could actually unite around a program of war powers reform. President Obama's unprecedented turn to Congress for explicit authority to stage a

151. See id. § 101 (enumerating the specific scenarios in which the President could unilaterally authorize the use of military force abroad and the proper principles according to which such force could be employed).

152. Id. § 102.

153. This is the phrase the $9 / 11$ Commission used in recommending structural change in Congress for oversight of homeland security. NAT'L COMM'N ON TERRORIST ATTACKS UPON THE U.S., THE 9/11 COMMISSION REPORT 421 (2004) [hereinafter 9/11 COMMISSION REPORT].

154. See Victoria Nourse, Misunderstanding Congress: Statutory Interpretation, the Supermajoritarian Difficulty, and the Separation of Powers, 99 GEO. L.J. 1119, 1126 (2011) (noting the consensus among political scientists that members of Congress care intensely about reelection).

155. See Katharine Q. Seelye \& Leslie Wayne, The Web Takes Ron Paul for a Ride, N.Y. TIMES, Nov. 11, 2007, http://www.nytimes.com/2007/11/11/us/politics/11paul.html?pagewanted =all (discussing with a visiting Duke law professor who ran Howard Dean's 2004 presidential campaign how the internet has led to decentralization of political funding).

156. AMY B. ZEGART, SPYING BLIND 154 (2007).

157. 9/11 COMMISSION REPORT, supra note 153.

158. NAT'L PREPAREDNESS GRP., BIPARTISAN POLICY CTR., TENTH ANNIVERSARY REPORT CARD: THE STATUS OF THE 9/11 COMMISSION RECOMMENDATIONS 16 (2011), available at http://bipartisanpolicy.org/sites/default/files/CommissionRecommendations.pdf. 
limited strike operation against Syria has revealed a complex political landscape with regard to war-making.

The Democrats are divided primarily among the "humanitarian interventionists" and "presidentialism skeptics." That is because some liberals believe U.S. military interventions can be effective tools for forestalling international atrocities, while others are wary of the utility of U.S. military interventions and, perhaps more profoundly, the breadth of presidential claims of authority to deploy U.S. military forces unilaterally.

The Republicans are divided between "military hawks" and "neoisolationists." The former are conservatives persuaded that radical Islamists have taken the place of Communists as a persistent, ubiquitous global enemy and that nearly unfettered presidential military discretion is essential to defeat their cause; the latter, like presidentialism skeptics, doubt the utility of U.S. military interventions and are inclined to resist international deployments because of their fiscal, as well as geopolitical consequences.

A legislative project to reinvigorate the cycle of accountability could potentially unite the neo-isolationists and presidentialism skeptics. It is noteworthy also that the draft Use of Force Act ${ }^{159}$ would have gone beyond the War Powers Resolution in legitimating presidential military initiative. It would authorize the President to use force, in conformity with the Act, to forestall imminent acts of terrorism ${ }^{160}$ and to protect internationally recognized rights of innocent and free passage in the air and on the seas. ${ }^{161}$

Providing explicit Congressional sanction for presidential action aimed at such purposes might win the support of both the humanitarian interventionists and perhaps even some military hawks. ${ }^{162}$

In any event, what is clear is that the kinds of institutional performance that Professors Zeisberg and Griffin both crave depend on reforms within Congress that will be motivated, if at all, only by external political pressures. What is necessary is that those pressures coalesce to support the institutionalization of new structures and processes that will enable the cycle of accountability these authors describe. President Obama's handling

159. See text accompanying notes $148-51$.

160. The requirement of "imminence" would no doubt be of concern should the Use of Force Act or something like it ever be reintroduced into Congress. My point is not, however, to endorse any particular wording but simply to point out the possibility of elaborating permissible grounds for presidential military deployments in a manner more thoroughgoing than the War Powers Resolution.

161. S. 564, 104th Cong. (1995) § 101 (a).

162. Peter M. Shane, Using the Syria Debate to Launch War Powers Reform, Huffington POST (Sept. 9, 2013, 9:57 AM), http://www.huffingtonpost.com/peter-m-shane/using-the-syriadebate-to_b_3881124.html. 
of Syria would seem to support this point. Americans are unlikely to learn any time soon what precise mix of decision-making factors led President Obama to invite Congress's participation in deciding on a military strike. One of those factors was quite probably the excuse his invitation provided for delaying a strike whose prospect was not proving popular either with international allies or with the American public ${ }^{163}$ —an entirely political consideration. But it would be just as surprising if the President were not focused on the domestic legal legitimacy that a legislative authorization to use military force would confer. Indeed, without that legal framing, it seems a fair guess that even the political utility of going to Congress would have been greatly reduced. So the question is how to get presidents to make this sort of legally influenced judgment more often.

The crux of my friendly amendment to the Zeisberg and Griffin analyses is simply this: I believe each understates the potential role of law in catalyzing those structures and processes that could lead to more effective interbranch deliberation. Even if legality does not-and perhaps should not-be the predominant factor in war-making decisions, what Professor Griffin calls “the nonlegalized Constitution” can still be helpfully infused by the values, attitudes, and analytic approaches associated with conscientious lawyering.

163. See Andrew Dugan, U.S. Support for Action in Syria is Low vs. Past Conflicts, GALLuP PoL. (Sept. 6, 2013), http://www.gallup.com/poll/164282/support-syria-action-lower-pastconflicts.aspx (finding only 36\% of Americans favored military action in Syria compared with $59 \%$ in Iraq, $82 \%$ in Afghanistan, and 62\% in the Persian Gulf). 